\title{
Field boundary effects on soil seed banks and weed vegetation distribution in an arable field with- out weed control (Vaucluse, France)
}

\author{
Thierry Dutoit ${ }^{\mathrm{a}}$, Éric Gerbaud ${ }^{\mathrm{a}}$, Jean-Marc Ourcival ${ }^{\mathrm{b}}$ \\ ${ }^{a}$ Université de Provence, Upresa / CNRS 6116 Imep, FST Saint-Jérôme, case 421 bis, 13397 Marseille cedex 20, France \\ ${ }^{\mathrm{b}}$ CNRS-Cefe, 1919 route de Mende, 34293 Montpellier cedex 05, France
}

(Received 3 March 1999; accepted 30 July 1999)

\begin{abstract}
Studies on the distribution of arable weed species relative to the field boundary have already been performed, although most of these studies have been realised in north-western Europe on intensively managed arable fields. Nevertheless, it is important to examine arable weed communities in more extensive cropping systems to increase our knowledge on how arable plant communities are constructed. Plant composition and seed bank of an arable weed community were sampled in an arable wheat field in Vaucluse (south-eastern France) at $1-\mathrm{m}$ intervals along five 25-m perpendicular transects from the herbaceous field boundary. The results showed that seed bank distribution and plant composition are primarily influenced by distance from the field boundary in the crop edge rather than soil characteristics or wheat density. (C) 1999 Inra/Éditions scientifiques et médicales Elsevier SAS.)
\end{abstract}

field boundary / crop edge / arable weeds / seed banks

Résumé - Effets de la lisière sur la distribution du stock semencier et des mauvaises herbes d'un champ cultivé sans désherbage (Vaucluse, France). De nombreuses études ont été réalisées sur la distribution des mauvaises herbes en relation avec la lisière du champ mais la plupart de ces travaux ont été menés dans les cultures intensives du nord-ouest de l'Europe. Cependant, il est également important d'étudier les communautés de mauvaises herbes dans des écosystèmes cultivés plus extensivement afin d'accroître nos connaissances sur les modalités de mise en place de ces communautés. La végétation et le stock semencier d'une communauté de mauvaises herbes ont été échantillonnés dans un champ de blé du département de Vaucluse (sud-est de la France) tous les mètres le long de cinq transects perpendiculaires à une lisière herbacée. Les résultats montrent que, dans les premiers mètres en bordure du champ, la distribution du stock semencier et la composition botanique sont en premier lieu influencées par la distance à la lisière herbacée plutôt que par les caractéristiques du sol ou la densité de blé. (@ 1999 Inra/Éditions scientifiques et médicales Elsevier SAS.)

lisière / bord du champ / mauvaise herbe / stock semencier

Communicated by Cesar Fernandez-Quintanilla (Madrid, Spain)

* Correspondence and reprints

thierry.dutoit@bioeco.u-3mrs.fr 


\section{Introduction}

In the last few decades, species diversity of arable fields in western Europe has decreased substantially $[1,4,5,14,24,35,39]$. Currently, vegetation in most arable fields is homogeneous and vast areas, or even countries, are characterised by a few dominant species, e.g. Galium aparine or Bromus sterilis [13, 33]. The main reasons for decreased species richness in arable fields are likely to be herbicide treatments for weed control and the increased use of fertilisers in recent decades $[15,28,37]$.

The field boundaries are commonly perceived by landowners to be a haven for weeds, pests and disease [32, 42]. However, informal observations suggest that crop edges (headlands and corners of arable fields) tend to be areas with high botanical diversity and previous surveys have also supported this view $[31,45]$. Most of these surveys were performed in intensive farming systems in north-western European countries (England, Denmark, Germany, Netherlands), and little information is available about the effects of field boundaries on arable weed distribution in the Mediterranean basin. Nevertheless, agricultural practices between north-western and south-eastern Europe are quite different especially with the persistence in the Mediterranean basin of traditional extensive arable management [6].

In this study, arable weed distribution according to distance from the field boundary was surveyed in an arable field located in the Vaucluse (southeastern France). This region is well known for its species-rich arable weed communities containing rare species $[19,20,23]$. The aims of this survey were primarily to examine the relationship between the distribution of arable weeds and distance from the field boundary as well as to understand the importance of soil conditions and seed banks in the spatial variability of soil surface vegetation. We compared our results with those obtained in intensive farming systems in north-western Europe.

\section{Materials and methods}

An arable field was chosen which had been drilled with a winter wheat crop in October 1997. This field was located in a farm in the Vaucluse $\left(5^{\circ} 26^{\prime} \mathrm{E}, 43^{\circ} 55^{\prime}\right.$ $N)$. The soil was calcareous with a large amount of clay. The field has always been cultivated with cereals (winter wheat in 1995 and barley in 1996) and has never received any herbicide treatments since the first ploughing of an old field several decades ago. This management is typical for a lot of fields in this area [18].

\subsection{Analysis of soil surface vegetation}

Five 25-m transects were laid out perpendicularly from the field boundary to the middle of the crop, with sampling points located at $1-\mathrm{m}$ intervals along each transect (125 quadrats). The direction of ploughing was parallel to the field boundary and the crop edge investigated was not a headland following the definition of Greaves and Marshall [22]. The transects were positioned away from the corner of the field to avoid any possible variation when compared with the other sides of the field. In May 1998, all dicotyledonous and grass weed species were identified at each point in a $1-\mathrm{m}^{2}$ quadrat and their seedlings were counted in a $400-\mathrm{cm}^{2}$ quadrat positioned in a corner of the $1-\mathrm{m}^{2}$ quadrat. Wheat density in the $400-\mathrm{cm}^{2}$ quadrats was estimated by counting the individuals. Jauzein [27] was used when necessary to help identify rare arable weeds. Nomenclature follows Tutin et al. [41].

\subsection{Analysis of soil seed bank}

The soil seed bank was sampled in January 1998. Soil cores were taken using a cylindrical steel tube with a $2-\mathrm{cm}$ radius (cross-sectional area $1.25 \times 10^{-3} \mathrm{~m}^{2}$ ) to a depth of $30 \mathrm{~cm}$, representing approximate ploughing depth. A total of $125(5 \times 25)$ soil samples and quadrats was examined (total surface area investigated: $16 \mathrm{dm}^{2}$ ). This is comparable with the optimum numbers of 100 $1.66 \times 10^{-3} \mathrm{~m}^{2}$ cores proposed by Barralis et al. [9].

The number of seeds in the soil samples was determined by allowing viable seeds to germinate [38]. Each soil core was broken down, placed on a $2 \mathrm{~cm}$ layer of sterile coarse sand in separate trays $(45 \times 30 \times 8 \mathrm{~cm})$, kept in an unheated greenhouse for 6 months and watered as necessary. Each tray was stirred at 2 -week intervals and emerging seedlings were counted and removed or replanted for later identification. Mamarot et al. [29] and Muller [34] were used when required for identification. The trays were moved around the greenhouse each week to minimise the effects of any non-uniform conditions. After 2 months, each sample was 
sprayed with gibberellic acid $\left(1 \mathrm{~g} \cdot \mathrm{L}^{-1}\right)$, based on Barralis and Chadoeuf's method [7,8].

\subsection{Environmental variables}

Spatial variability in the weed seed bank was compared with the following environmental variables.

\subsubsection{Physical and chemical characteristics of the soil}

In January 1998, three soil samples were taken at $20 \mathrm{~cm}$ deep for each of the five transects. The first soil core was located near the field boundary $(\mathrm{a}, 0 \mathrm{~m})$, the second in the middle of the transect $(\mathrm{b}, 13 \mathrm{~m})$ and the third in the middle of the crop (c, 25 m). In April 1998, at the same points, soil porosity was measured by burying three cylinders of $300 \mathrm{~cm}^{3}$ at $20 \mathrm{~cm}$ deep for each of the five transects. After drying at $105^{\circ} \mathrm{C}$, the soil cores were weighted and the apparent density calculated (D). The porosity (P) was calculated following the formula:

$$
\mathrm{P} \%=\left(2.6^{*}-\mathrm{D}\right) / 2.6
$$

( 2.6 is a constant for the real density of soils).

Soil $\mathrm{pH}$ was determined in a slurry with water using a glass electrode. Organic nitrogen and carbon were analysed using the Kjeldahl and Anne methods, respectively. Analysis of extractable major ions $\left(\mathrm{K}^{+}, \mathrm{Mg}^{2+}\right.$, $\mathrm{PO}_{4}^{3-}, \mathrm{Ca}^{2+}$ ) was performed by atomic absorption spectrophotometry after extraction with ammonium acetate and EDTA $(\mathrm{pH}=4.65)$.

\subsubsection{Profiles of photosynthetically active radiation (PAR) through the wheat canopy}

In May 1998, PAR was measured at 1-m intervals along the five transects through the wheat canopy on the soil surface. Measurements were made on the same day during similar sunny hours between $11.00 \mathrm{a} . \mathrm{m}$. and 13.00 p.m. using a sensor with a light sensitive surface of $95 \times 1 \mathrm{~cm}$ (EMS 7A, University of Provence, Marseille, France). The reference PAR sensor $(18 \times$ $1 \mathrm{~cm}$ ) was placed above the wheat canopy using a standard tripod socket to measure incident radiation. PAR values from the line sensor were calculated to percentages of incident radiation.

\subsection{Statistical analyses}

Several multivariate analyses were performed using ADE software. i) A principal component analysis (PCA) was performed on a [ 8 variables $\times 15$ samples] matrix to identify the main soil gradients involved in the distribution of arable weed communities. ii) Two correspondence analyses (CA) were performed on the [25 quadrats $\times 67$ species] matrix of the soil surface vegetation and the [25 quadrats $x 42$ species] matrix of the soil seed bank after pooling the data of the five different transects for each distance. This was in order to compare the composition and structure of the arable weed community according to distance from the field boundary.

To compare the relationships between species composition in the soil seed bank and on the soil surface with different environmental variables, a canonical correspondence analysis (CCA) was used (ADE Software). A pair co-structure analysis was also used to compare the differences between the distribution of soil seed banks and the soil surface vegetation [40]. Sorensens similarity indices (Cs) were calculated to compare seed bank composition with soil surface vegetation. Species richness, density, diversity (Shannon index) and evenness for the seed bank and soil surface vegetation (arable weeds, segetal species group and individual species) were analysed according to distance from the arable field boundary using the Anova test. Comparison of these dependent variables with the environmental variables was made using simple linear regressions (Statview software).

\section{Results}

Seventy-six species were identified during the study: 62 in soil surface vegetation, 40 in soil seed bank and 26 species in both (table I). Sixteen species could be considered to have segetal species characteristics (species with their optimal distribution in cereal crops) for south-eastern France based on Guende and Olivier [23]. Most of these species are included in the phytosociological order of Secalinetalia Br. Bl. 1952, and Secalinion-mediterraneum Tx 1937 alliance following Barbero et al. [6].

Sorensens index value $(\mathrm{Cs}=0.46)$ and the pair co-structure analysis (similarity: $3.2 \%$ ) revealed that composition and distribution of the soil seed bank was significantly different from that of soil surface vegetation. The pair co-structure analysis also revealed that total inertia ( $\mathrm{Ti}$ ) of the soil seed 
Table I. Mean numbers per $\mathrm{m}^{2}$ of seedlings recorded in the seed banks and soil surface vegetation $*=$ segetal species of Provence based on Guende \& Olivier [23].

\begin{tabular}{|c|c|c|c|c|c|}
\hline Species & $\begin{array}{c}\text { Soil seed } \\
\text { banks } \\
\text { (seedlings } / \mathrm{m}^{2} \text { ) }\end{array}$ & $\begin{array}{c}\text { Soil surface } \\
\text { vegetation } \\
\text { (seedlings } / \mathrm{m}^{2} \text { ) }\end{array}$ & (se & $\begin{array}{l}\text { Soil seed } \\
\text { banks } \\
\text { seedlings } / \mathrm{m}^{2} \text { ) }\end{array}$ & $\begin{array}{c}\text { Soil surface } \\
\text { vegetation } \\
\text { (seedlings } / \mathrm{m}^{2} \text { ) }\end{array}$ \\
\hline Acinos arvensis & 55.01 & - & Lolium rigidum & 1.14 & 0.22 \\
\hline Adonis annua * & - & 0.24 & Lotus hispidus & 1.14 & - \\
\hline Agrimonia eupatoria & - & 0.03 & Medicago lupulina & - & 0.01 \\
\hline Ajuga chamaepitys & 15.46 & - & Melilotus officinalis & 77.57 & 5.52 \\
\hline Ammi visnaga & 126.83 & - & Muscari comosum & - & 0.11 \\
\hline Anagallis arvensis & 295.46 & 10.12 & Myagrum perfoliatum * & - & 0.17 \\
\hline Anchusa italica & - & 0.14 & Neslia paniculata * & - & 0.01 \\
\hline Asperula arvensis * & - & 0.76 & Ornithogalum umbellatum & 1.14 & 0.42 \\
\hline Avena sativa & - & 0.07 & Papaver argemone* & - & 0.21 \\
\hline Bifora radians* & - & 0.02 & Papaver rhoeas* & 30.8 & 0.36 \\
\hline Bromus sterilis & - & 0.02 & Phleum pratense & 1.14 & - \\
\hline Bupleurum subovatum & 3.3 & 0.9 & Picris echioides & 19.78 & 0.02 \\
\hline Carex flacca & 4.43 & - & Picris hieracioides & - & 0.02 \\
\hline Caucalis platycarpos * & - & 0.02 & Plantago major & 4.43 & - \\
\hline Centaurea scabiosa & - & 0.03 & Polygonum arviculare & 193.05 & 9.33 \\
\hline Centaurea solstitialis & - & 0.71 & Potentilla reptans & 45.45 & 0.5 \\
\hline Chenopodium vulvaria & 333.73 & 1.83 & Ranunculus arvensis* & 3.3 & 1.15 \\
\hline Cirsium arvense & 3.3 & 2.46 & Rapistrum rugosum & 202.75 & 2.32 \\
\hline Conringia orientalis * & - & 0.03 & Rubus sp. & - & 0.28 \\
\hline Convolvulus arvensis & 3.3 & 1.69 & Rumex obtusifolius & 2.27 & 0.18 \\
\hline Coronilla scorpioides & - & 0.3 & Sanguisorba minor & 4.43 & 0.16 \\
\hline Daucus carota & 3.3 & - & Senecio erucifolius & - & 0.3 \\
\hline Dipsacus fullonum & 4.43 & - & Setaria viridis & 21.02 & 0.22 \\
\hline Echinops ritro & - & 0.19 & Sideritis hirsuta & 112.29 & 2.8 \\
\hline Elytrigia repens & - & 0.43 & Silene vulgaris & - & 0.01 \\
\hline Eryngium campestre & - & 0.02 & Sonchus asper & 9.89 & 0.18 \\
\hline Euphorbia falcata & 9.89 & 1.72 & Torilis arvensis & 90.41 & 9.66 \\
\hline Fallopia convolvulus & 40.87 & 3.6 & Trifolium campestre & 3.3 & - \\
\hline Fumaria officinalis & - & 0.74 & Trifolium medium & 4.43 & - \\
\hline Galeopsis ladanum * & 13.18 & 7.68 & Trifolium pratense & 3.3 & - \\
\hline Galium tricornutum * & 1.14 & 7.21 & Trifolium repens & - & 0.02 \\
\hline Geranium dissectum & - & 0.01 & Triticum aestivum & - & 32.35 \\
\hline Gladiolus italicus * & - & 2.4 & Turgenia latifolia* & - & 0.06 \\
\hline Hypericum perforatum & 5.57 & - & Tussilago farfara & - & 0.01 \\
\hline Iberis pinnata $*$ & - & 0.01 & Verbena officinalis & 9.89 & - \\
\hline Kickxia spuria & 147.51 & 1.67 & Veronica praecox* & - & 0.28 \\
\hline Lathyrus hirsutus & - & 0.07 & Vicia sativa & - & 0.15 \\
\hline Linum usitatissimum & 43.98 & 2.04 & Unidentified dicotyledons & 11.02 & 0.11 \\
\hline Lithospermum arvense & - & 0.06 & Unidentified grass & 24.21 & 0.01 \\
\hline
\end{tabular}

bank matrix $(\mathrm{Ti}=9.212)$ showed a higher variability than the soil surface vegetation matrix $(\mathrm{Ti}=1.848)$. This result indicates that distribution of species in the soil surface vegetation is more homogeneous than in the soil seed bank.
The PCA performed on the environmental matrix revealed which soil characteristics influence soil fertility from the field boundary and between the five transects (figure 1 ). The first two axes accounted for almost $60 \%$ of total variation, with 


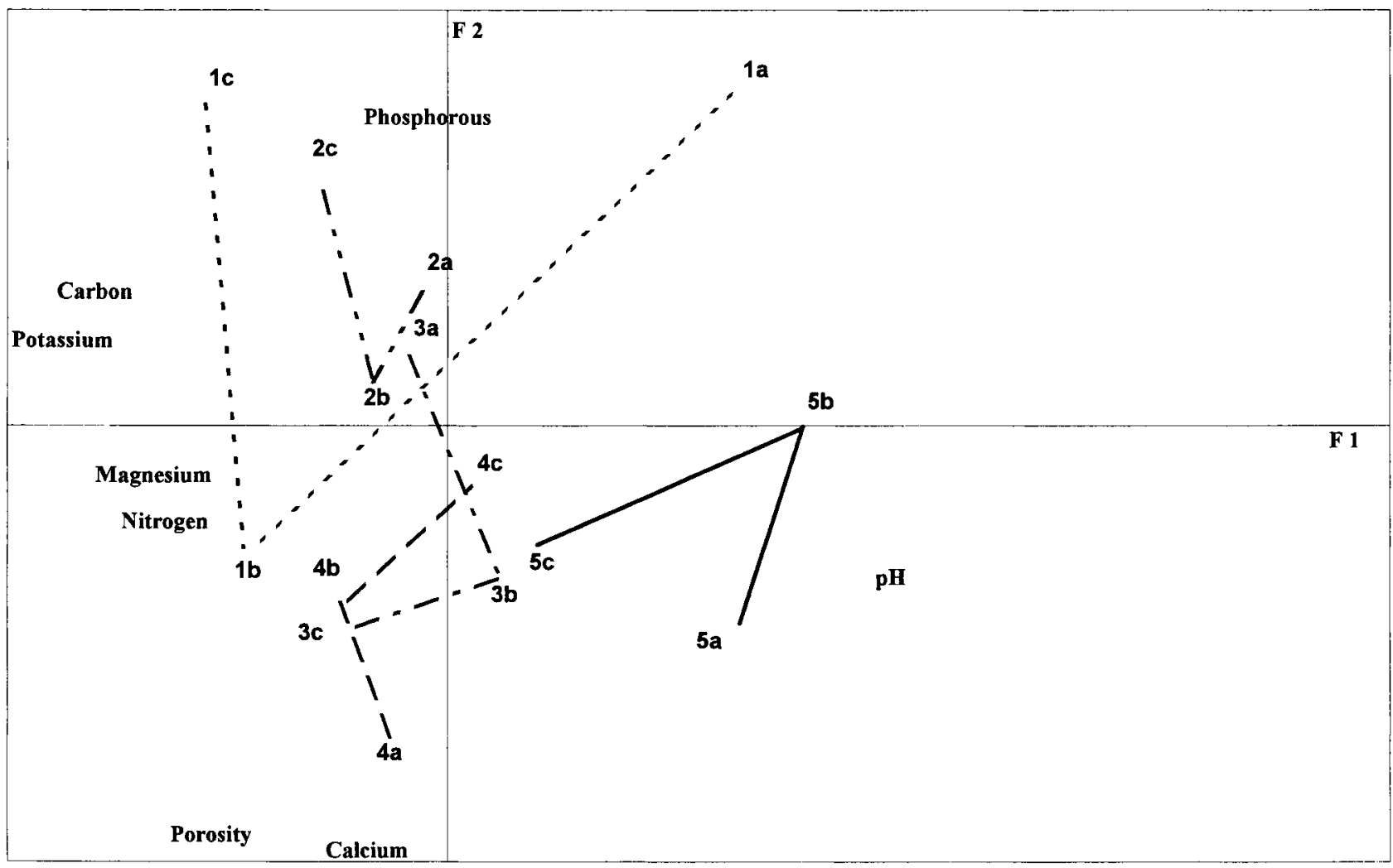

Figure 1. PCA performed on the soil characteristics data sampled at the beginning $(\mathrm{a}, 0 \mathrm{~m})$, middle $(\mathrm{b}, 13 \mathrm{~m})$ and end (c, $25 \mathrm{~m})$ of the five transects (1-5).

$41.7 \%$ for axis 1 (variance: 3.33 ) and $18.9 \%$ for axis 2 (variance: 1.51 ). Axis 1 is strongly influenced by $\mathrm{pH}$ (contribution: 22.6) and soil samples with a high $\mathrm{pH}(5 \mathrm{a}, 5 \mathrm{~b}, 5 \mathrm{c})$. However, axis 1 is also influenced by $\mathrm{K}$ (23.3), C (17.95) and $\mathrm{Mg}$ (14.9) concentrations and soil samples $1 \mathrm{~b}, 1 \mathrm{c}$ are characterised by high contents of these elements. Axis 1 illustrates fertility gradient for soil samples from the first transect, taken from the left-hand side of the crop, to the fifth transect, taken from the righthand side of the crop. However, no fertility gradient could be identified from the field boundary to the middle of the crop (figure 1). These results were confirmed by the Anova tests which showed significant differences only for phosphorous, whose values increased from the field boundary to the middle of the crop (table II). Significant differ- ences were also found for $\mathrm{pH}$ and porosity between the five transects (table $I I$ ).

The first axis for the two CA performed on soil surface vegetation (figure $2 a$ ) and soil seed bank (figure $2 b$ ), respectively, accounted for 23 and $13.3 \%$ of total variation, respectively. Axes 1 were strongly influenced by species which occurred only in the samples located at 1 and $2 \mathrm{~m}$ from the field boundary. Particularly, Agrimonia officinalis, Geranium dissectum, Lolium rigidum, Medicago lupulina, Lathyrus hirsutus, Picris echioides and Eringyum campestre for soil surface vegetation (figure $2 a$ ) and Phleum pratense, Dipsacus fullonum, Carex flacca and Hypericum perforatum for soil seed bank (figure $2 b$ ).

Total inertia of the two CCAs performed on environmental variables by soil surface vegetation matrix and seed bank matrix were 0.12 and 0.09 , 
Table II. Soil characteristics of samples taken at three points (a, $0 \mathrm{~m}$ ), middle (b, $13 \mathrm{~m})$ and end (c, $25 \mathrm{~m})$ of the transects $(\mathbf{n}=5)$ (significance $: * p<0.005)$

\begin{tabular}{lllllllll}
\hline & $\mathrm{pH}$ & Porosity & $\mathrm{C} \% 0$ & $\mathrm{~N} \% 0$ & $\mathrm{P} \% 0$ & $\mathrm{~K} \% 0$ & $\mathrm{Ca} \% 0$ & $\mathrm{Mg} \% 0$ \\
\hline$(\mathrm{n}=5)$ & & & & & & & & \\
$\mathrm{a}$ & 8.25 & 0.550 & 28.16 & 0.838 & $0.004^{*}$ & 0.406 & 10.52 & 0.220 \\
$\mathrm{~b}$ & 8.23 & 0.544 & 31.97 & 0.878 & 0.007 & 0.440 & 10.71 & 0.180 \\
$\mathrm{c}$ & 8.27 & 0.536 & 27.18 & 0.816 & 0.006 & 0.400 & 10.61 & 0.156 \\
$(\mathrm{n}=3)$ & & & & & & & & \\
1 & $8.14^{*}$ & $0.550^{*}$ & $35.25^{*}$ & 0.847 & 0.007 & 0.433 & 10.59 & 0.200 \\
2 & $8.23^{*}$ & 0.533 & $34.84^{*}$ & 0.867 & 0.006 & 0.437 & 10.42 & 0.210 \\
3 & $8.26^{*}$ & $0.580^{*}$ & 27.46 & 0.840 & 0.005 & 0.427 & 10.87 & 0.203 \\
4 & $8.29^{*}$ & $0.560^{*}$ & $26.64^{*}$ & 0.907 & 0.006 & 0.393 & 10.70 & 0.160 \\
5 & $8.33^{*}$ & $0.493^{*}$ & $21.31^{*}$ & 0.760 & 0.006 & 0.387 & 10.48 & 0.153 \\
\hline
\end{tabular}

respectively. Inertia of axis $1 \mathrm{CCA}$ and axis $1 \mathrm{CA}$ were quite low, 0.26 and 0.29 , respectively. Thus, no clear correlation was apparent between environmental variables, soil surface vegetation or seed bank distribution in the arable field even when wheat density was considered as an environmental variable.

Species richness (number of species found per $\mathrm{m}^{2}$ ), diversity (Shannon index) and evenness of the seed bank and soil surface vegetation showed no significant differences between the plots located near the field boundary ( 1 and 2) and the others plots (3-25). Only the soil surface vegetation density of plot 1 was significantly lower than the others. Nevertheless, species richness, diversity, density and evenness showed significant differences between each transect (table III).

Individual species densities were significantly higher in the crop edge compared to the others plots with a probability of error of $P<0.05$ for only four species: Anagallis arvensis, Bupleurum subovatum, Galium tricornutum and Polygonum arviculare (table IV). Only Galium tricornutum is considered by Guende and Olivier [23] as a typical segetal species of the Luberon regional park.

Simple linear regression analyses were performed for species richness, diversity, density and evenness of the seed bank, soil surface vegetation and environmental variables (soil characteristics, PAR values). Wheat density showed a positive significant relationship only with the arable weeds of
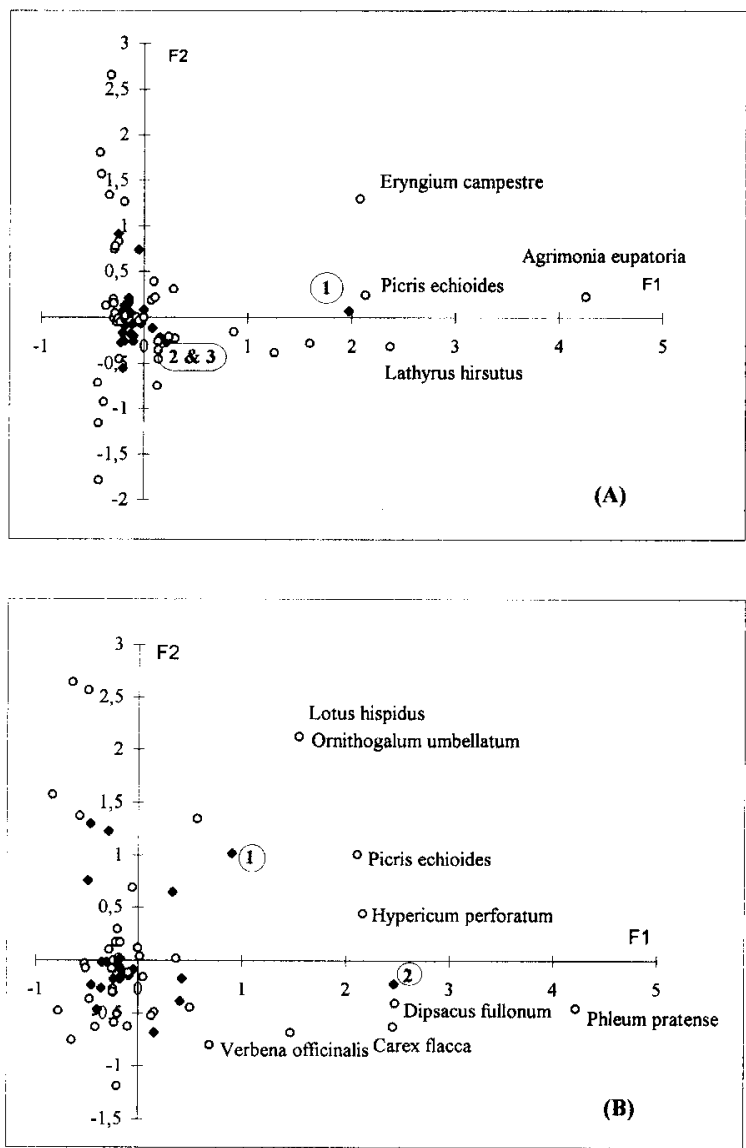

Figure 2. (a) CA performed on the main composition of soil surface vegetation plots and (b) $\mathrm{CA}$ performed on the main composition of soil seed bank data. $\bigcirc=$ species, $\boldsymbol{\nabla}=$ plots. Only the species and samples showing a significant correlation with axis 1 have been written out in full. In (a), co-ordinates of Agrimonia eupatoria are the same as Geranium dissectum, Medicago lupulina and Prunus spinosa. 

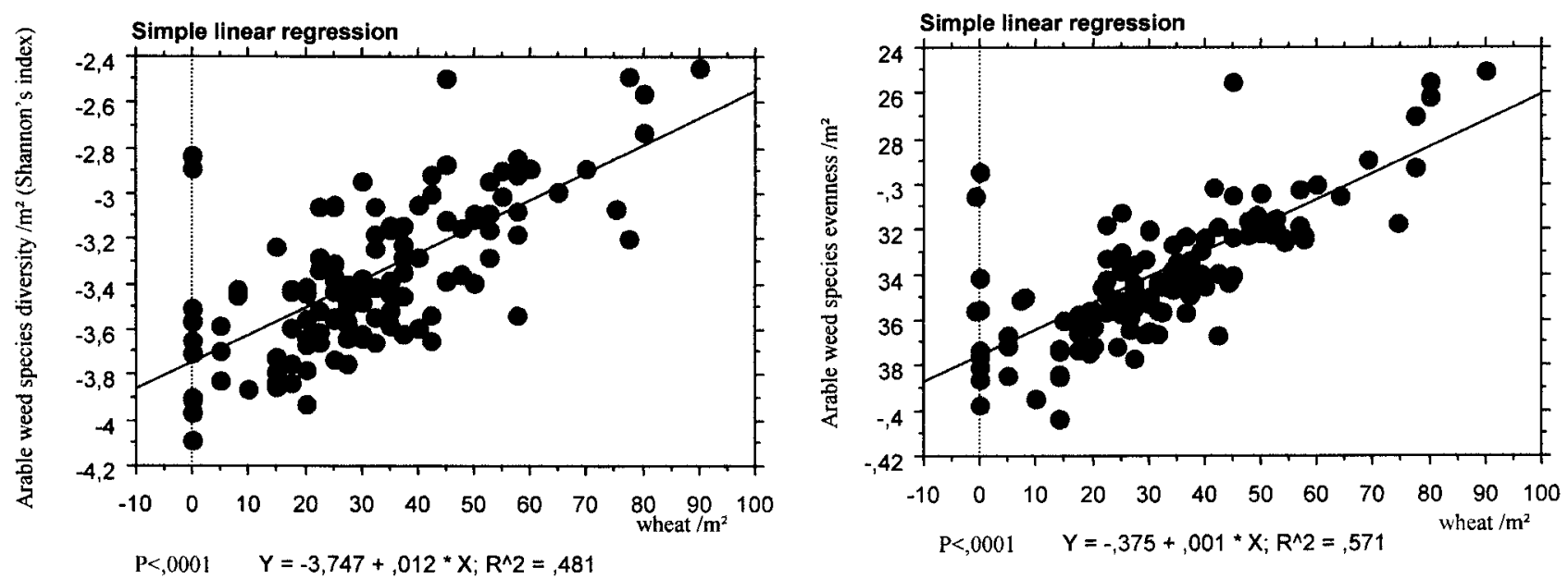

Figure 3. Simple linear regression between diversity (a) and evenness (b) of the soil surface vegetation and wheat density (wheat $/ \mathrm{m}^{2}$ ).

soil surface vegetation diversity and evenness (figure $3 a, b)$, with a probability of error of $P<0.0001$. No positive relationship or significant difference has been found between wheat density and the distance from field edge (table III) or wheat density and species richness, density, diversity and evenness for the group of segetal species.

Significant differences of PAR values through the wheat canopy could be observed between the first three points (1-3) situated in the crop edge near the field boundary and the others points, with a probability of error of $P<0.05$ (table $I I I$ ). Nevertheless, no positive relationship has been found between PAR values and wheat density or PAR values and species richness, density, diversity and evenness for the group of segetal species.

\section{Discussion}

Multivariate analysis (AFC) showed that some species were restricted to the outer $3 \mathrm{~m}$ of the field boundary for soil surface vegetation and $2 \mathrm{~m}$ for soil seed bank. Most of these species are boundary non-arable species present in the old field situated near the crop (e.g. Agrimonia officinalis, Lolium rigidum, Medicago lupulina, Lathyrus hirsutus, Picris echioides, Eringyum campestre, Phleum pratense, Dipsacus fullonum, Carex flacca, Hypericum perforatum, etc.). Similar distributions were found by Marshall [31] and Wilson and Aebischer [45] for typical boundary species and shady ruderal sites in the arable fields in northwestern Europe (Anthriscus sylvestris, Heracleum sphondylium, Urtica dioica, Galium aparine, Cirsium arvense, Lapsana communis, Silene alba). It is possible that seedlings of boundary species in the crop edge may originate from parent plants of the field boundary. A previous study of seed spread from a weedy area into an adjacent cultivated field indicated that seed dispersal for most species was limited [26].

Other reasons must therefore be found to account for the distribution of arable weeds. Farming operations on the field headland differed considerably from those practised on the rest of the arable field. Farming machinery often turns on the headland, resulting in lower crop yields. Boatman and Soherton [11] and Wilson [44] have already demonstrated differences between crop yields near the field edge and yields in midfield, and implying lower competitive effects near the crop edge. Kleijn and van der Voort [28] also support this 
Table III. PAR values, wheat density, species-richness (R), density (D), diversity $(H)$ and evenness $\left(\mathrm{H}^{\prime}\right)$ of soil seed banks and surface vegetation sampled at one meter intervals along the transects $(n=5)(p *<0.05)$.

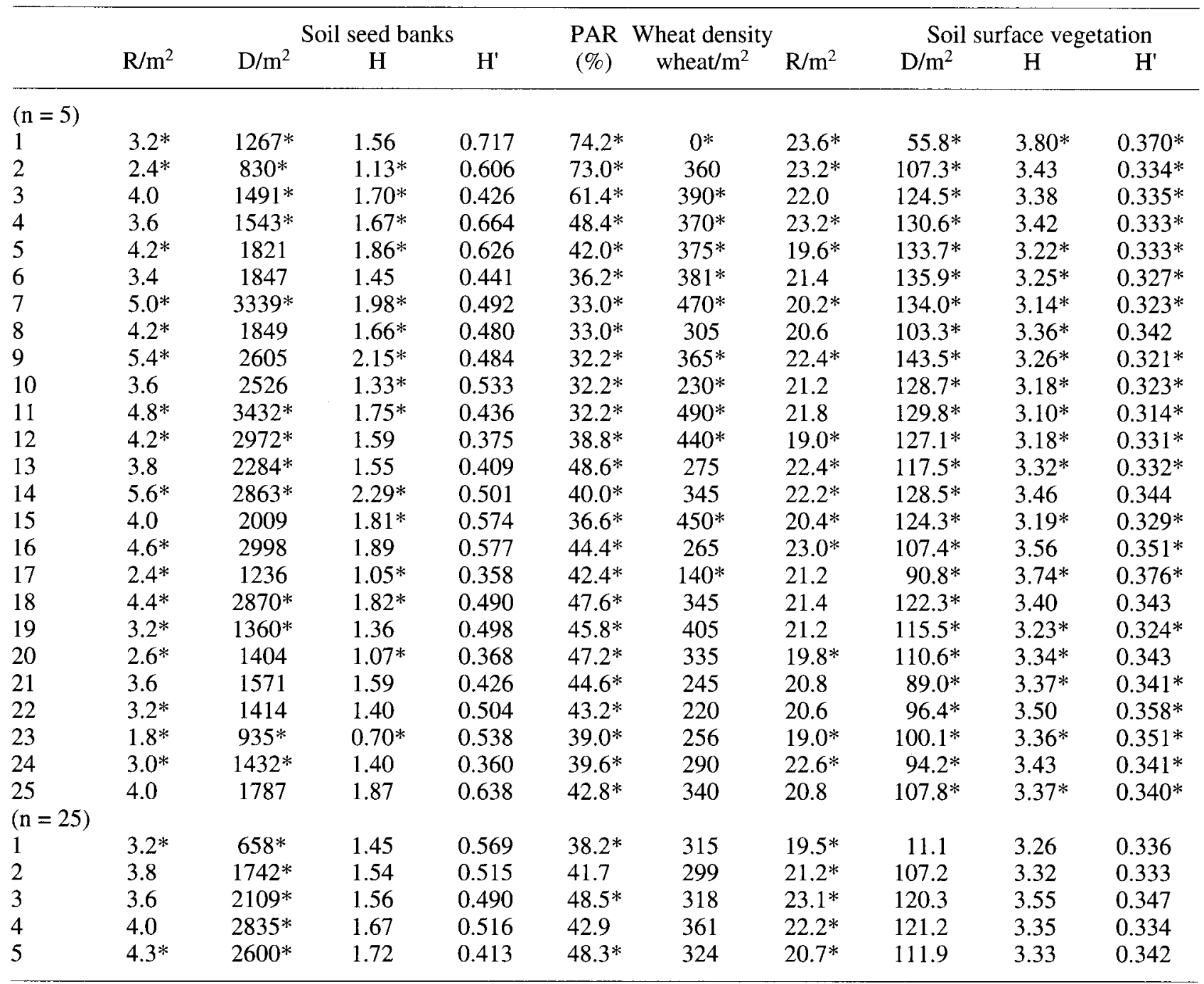

assertion and found that, even in non-headland crop edges, light penetration is higher in the outer metres of the crop and that in fertilised crop edges these light levels determine species richness and individual plant performance. Their results are confirmed by our study because the cover of the wheat measured by the PAR values (table III) was significantly higher in the first $3 \mathrm{~m}$ in the crop edge near the field boundary than the other plots even with no gradient in the distribution of wheat density in the arable field (table III). Then, the presence of typical grassland species and high seedling density in the crop edge could be explained by this availability of light. Another explanation could be the effects of crop competition, which increase across the arable field, creating more opportunities for these species to develop near the field boundary than in sites located further away [21].

Our study showed that species richness, diversity and evenness in the seed banks and soil surface vegetation were not higher in plots sampled near 
Table IV. Seedling density per $\mathrm{m}^{2}$ of 4 species sampled in the surface vegetation at one meter intervals along the transects $(n=5)(p *<0.05)$

\begin{tabular}{|c|c|c|c|c|}
\hline & Anagallis arvensis & Bupleurum subovatum & Galium tricornutum & Polygonum arviculare \\
\hline \multicolumn{5}{|c|}{$(\mathrm{n}=5)$} \\
\hline 1 & $14.00^{*}$ & $0.40^{*}$ & $1.00^{*}$ & $1.00^{*}$ \\
\hline 2 & $9.30^{*}$ & $0.40^{*}$ & $1.80 *$ & $2.20^{*}$ \\
\hline 3 & $21.50^{*}$ & $0.60 *$ & $3.20 *$ & $4.20 *$ \\
\hline 4 & $20.50^{*}$ & $1.00^{*}$ & $2.20^{*}$ & $9.40 *$ \\
\hline 5 & $18.60^{*}$ & $0.20^{*}$ & $4.00^{*}$ & $15.10^{*}$ \\
\hline 6 & $20.00^{*}$ & $0.20 *$ & $6.90^{*}$ & $16.00 *$ \\
\hline 7 & $3.60^{*}$ & $0.40^{*}$ & $9.70^{*}$ & $14.00 *$ \\
\hline 8 & $5.10^{*}$ & $0.40^{*}$ & 7.80 & $7.30^{*}$ \\
\hline 9 & $5.60 *$ & $0.40^{*}$ & $6.30^{*}$ & $25.00^{*}$ \\
\hline 10 & $2.20^{*}$ & $0.80^{*}$ & $12.70^{*}$ & $20.00 *$ \\
\hline 11 & $3.40 *$ & $0.00 *$ & $14.50^{*}$ & $14.50^{*}$ \\
\hline 12 & $7.90 *$ & $0.20^{*}$ & $10.20 *$ & $7.30^{*}$ \\
\hline 13 & $7.90 *$ & $0.20 *$ & 6.90 & $17.10^{*}$ \\
\hline 14 & $10.30 *$ & $0.20^{*}$ & 5.90 & $15.50^{*}$ \\
\hline 15 & $10.70^{*}$ & $0.20^{*}$ & 5.00 & $14.10^{*}$ \\
\hline 16 & $10.70 *$ & $1.00^{*}$ & 5.50 & 7.50 \\
\hline 17 & $8.20^{*}$ & $1.00 *$ & 4.40 & $7.30^{*}$ \\
\hline 18 & $9.10^{*}$ & $1.00^{*}$ & $10.90^{*}$ & $6.30^{*}$ \\
\hline 19 & $13.70^{*}$ & $1.40^{*}$ & 6.20 & $3.20^{*}$ \\
\hline 20 & $6.00^{*}$ & $1.20 *$ & $10.10^{*}$ & $6.60^{*}$ \\
\hline 21 & $7.30 *$ & $1.20^{*}$ & 6.60 & $4.60^{*}$ \\
\hline 22 & $9.70^{*}$ & $3.40^{*}$ & $11.30^{*}$ & $3.20^{*}$ \\
\hline 23 & $13.60^{*}$ & $3.40 *$ & 8.70 & $3.60^{*}$ \\
\hline 24 & $6.40^{*}$ & $1.80^{*}$ & 7.30 & $3.20^{*}$ \\
\hline $\begin{array}{l}25 \\
(\mathrm{n}=\end{array}$ & $7.70^{*}$ & $1.40^{*}$ & $11.20^{*}$ & $5.10^{*}$ \\
\hline 1 & 10.16 & $0.84 *$ & $4.66^{*}$ & $14.44 *$ \\
\hline 2 & $7.48 *$ & $0.44^{*}$ & 7.54 & 9.66 \\
\hline 3 & $12.30^{*}$ & $0.64 *$ & 6.50 & $8.64 *$ \\
\hline 4 & 10.12 & $0.84^{*}$ & 7.68 & $8.22 *$ \\
\hline 5 & 10.54 & $1.72^{*}$ & $9.68 *$ & $5.70^{*}$ \\
\hline
\end{tabular}

the field boundary than in midfield plots. These results are opposed to those found by Marshall [30] or Wilson and Aebischer [45]. However, the differences could be explained by the absence of herbicide treatment. In spite of the fact that, in their studies, weed seedlings were surveyed before herbicide application, the differences in distribution were nonetheless probably due to the cumulative effects of herbicide and nitrogen applications in previous years (Wilson, pers. Comm.). In an intensive farming system, most weed seedlings in the middle of the field are eliminated by herbicide treatments and the only plants left are either ones which germinate after cultivation or are resistant to the herbicide used. Because the crop edge is usually cultivated and sprayed using a different pattern from that of the main part of the arable field, it could act as a refuge for most of the arable weed flora which would increase species richness and plant diversity [12, 42, 43].

The positive relationship between wheat density, arable weed diversity and evenness (figure $3 a, b$ ) could not be explained by the distance from the field margin. Only localised changes that favour 
the crop could also favour the diversity and evenness of the arable weeds community. These results are in contrast with those of Kleijn and van der Voort [28] but their work took place in an intensive farming system in Netherlands (pesticide drift, fertilisation, high wheat productivity, etc.). Then, it is difficult to make valuable comparisons with our study site localised in south-eastern France.

The CCA and linear regression analyses between seed bank, soil surface vegetation and the chemical characteristics of the soil showed no significant correlations. These results confirmed those of Albrecht and Pilgram [3] and Palmer and Maurer [36] who found that former management (previous cultivation and farming) is a more significant factor in determining the distribution of arable weed flora than environmental variables in small areas.

No distinct differences between the environmental relationships in the soil seed bank and soil surface vegetation could be observed using the pair co-structure analysis and Sorensens index. These results agree with other studies $[2,10,17,45]$. In arable soils, the spatial pattern that exists immediately after seed rain is modified by agricultural practices and because farm machinery can transport weed seeds. Combine harvesters, in particular, can carry or concentrate weed seeds $[16,25]$. Because the soil surface vegetation is more affected by the mechanical practices than the soil seed bank, the heterogeneity of soil seed bank is higher as revealed by the pair co-structure analysis.

An EEC project for the conservation of speciesrich crop edges has recently been initiated. This project includes reducing wheat seedling density on crop edges to increase segetal species richness. This approach was based on previous studies conducted in northern Europe [45]. However, our results showed that this type of action could be more beneficial to the boundary species than to the segetal species of Mediterranean fields. In our case, segetal species are not only limited to field edges in contrast to arable weeds in the intensive crop in northern Europe. In these intensive cropping systems prevailing in northern Europe, field margin management is crucial to conservation of endangered arable species. But, in southern France, where cereals are grown very extensively without agrochemical inputs, arable plant conservation may need to be approached on a 'whole-field' basis rather than on a field-margin basis as practised in northern Europe.

Acknowledgements: We would like to thank Professor Maurice Roux and Dr Frank Torre for statistical analyses, Dr Christiane Rolando, Mr Bernard Hill and Ms Delphine Auvré for technical support. Acknowledgements should also be made to Mr André Armand who granted us access to his farm. This work was supported by a grant from the French Foundation $\left(\mathrm{n}^{\circ}\right.$ 97008577).

\section{References}

[1] Albrecht H., Changes in the arable weed flora of Germany during the last five years, 9th EWRS Symposium, Budapest, 1995, 41-48.

[2] Albrecht H., Foster E.M., The weed seed bank of soils in a landscape segment in southern Bavaria. I. experimental sites, seed content, species composition and spatial variability, Vegetatio 125 (1996) 1-10.

[3] Albrecht H., Pilgram M., The weed seed bank of soils in a landscape segment in southern Bavaria. II. Relation to environmental variables and to the surface vegetation, Plant Ecol. 131 (1997) 31-43.

[4] Andraesen C., Stryhn H., Streibig., Decline of the flora in Danish arable fields, J. Appl. Ecol. 33 (1996) 619-626.

[5] Aymonin G., Les messicoles vont-elles disparaitre ?, Science et Nature 49 (1962) 3-9.

[6] Barbero M., Loisel R., Quézel P., Incidence des pratiques culturales sur la flore et la végétation des agrosystèmes en région méditerranéenne, C. R. Soc. Biogeogr. 59 (1984) 463-473.

[7] Barralis G., Chadoeuf R., Étude de la dynamique d'une communauté d'adventice. I. Evolution de la flore adventice au cours du cycle végétatif d'une culture, Weed Res. 20 (1980) 231-237.

[8] Barralis G., Chadoeuf R., Potentiel semencier des terres arables, Weed Res. 27 (1987) 417-424.

[9] Barralis G., Chadoeuf R., Gouet J.P., Essai de détermination de la taille de l'échantillon pour l'étude du potentiel semencier d'un sol, Weed Res. 26 (1986) 291-297. 
[10] Barralis G., Dessaint F., Chadoeuf R., Relation flore potentielle-flore réelle de sols agricoles de Côted'Or, agronomie 16 (1996) 453-463.

[11] Boatman N.D., Soherton N.W., The agronomic consequences and costs of managing field margins for game and wildlife conservation, Aspects Appl. Biol. 17 (1988) 47-56.

[12] Chancellor R.J., Changes in the weed flora of an arable field cultivated for 20 years, J. Appl. Ecol. 22 (1985) 491-501.

[13] Chancellor R.J., Froud-Williams R.J., Weeds problems of the next decade in Britain, Crop Prot. 5 (1986) 66-72.

[14] Dalmas J.P., Faut-il sauver les mauvaises herbes ? Conservatoire Botanique de Gap-Charance, Gap, 1997.

[15] Dekker J., Weed diversity and weed management, Weed Sci. 45 (1997) 357-363.

[16] Dessaint F., Chadoeuf R., Barralis G., Spatial pattern analysis of weed seeds in the cultivated soil seed bank, J. Appl. Ecol. 28 (1991) 721-730.

[17] Dessaint F., Chadoeuf R., Barralis G., Nine years' soil seed bank and weed vegetation relationships in an arable field without weed control, J. Appl. Ecol. 34 (1997) 123-130.

[18] Dutoit T., Hill B., Mahieu P., Gerbaud E., Restauration et conservation de communautés d'espèces ségétales in situ: des coteaux de la basse vallée de Seine aux cultures extensives du Parc Naturel Régional du Luberon, Bull. Soc. Bot. Centre-Ouest 18 (1999) (in press).

[19] Filosa D., Situation de quelques espèces végétales messicoles en haute-Provence occidentale, Bull. Soc. Bot. Centre-Ouest 16 (1985) 61-79.

[20] Filosa D., La régression des messicoles dans le sud-est de la France, in: J.P. Dalmas, (éds.), Faut-il sauver les mauvaises herbes ? Conservatoire Botanique National de Gap-Charance, Gap, 1997, pp. 67-74.

[21] Firbank L.G., Interactions between weeds and crops, in: Firbank L.G., Carter N., Darbyshire J.F., Potts G.R. (Eds.), The Ecology of Temperate Cereal Fields, Blackwell Scientific Publications, Oxford, 1991, pp. 209-231.

[22] Greaves M.P., Marshall E.J.P., Field margins definitions and statistics. in: Way J.M., Greig-Smith P.W. (Eds.), Fields Margins, BCPC Monograph, 35, 1987, pp. 85-94.

[23] Guende G., Olivier L., Les mesures de sauvegarde et de gestion des plantes messicoles du Parc naturel régional du Luberon, in: Dalmas J.P. (Eds.), Faut-il sauver les mauvaises herbes ? Conservatoire Botanique National de Gap-Charance, Gap, 1997, pp. 179-187.

[24] Holzner W., Weed species and weed communities, Vegetatio 38 (1978) 13-20.

[25] Howard C.L., Mortimer A.M., Gould P., Putwain P.D., Cousens R., Cussans G.W., The dispersal of weeds; seed movement in arable agriculture, Proceedings of the British Crop Protection Conference, Weeds, 1991, 821-828.

[26] Hume L., Archibold O.W., The influence of a weedy habitat on the seed bank of an adjacent cultivated field, Can. J. Bot. 64 (1986) 1879-1883.

[27] Jauzein P., Flore des champs cultivés, Inra, Paris, 1995.

[28] Kleijn D., van der Voort L.A.C., Conservation headlands for rare arable weeds: the effects of fertilizer application and light penetration on plant growth, Biol. Conserv. 81 (1997) 57-67.

[29] Mamarot J., Psarski P., Rouquier R., Mauvaises herbes des cultures, Acta, Paris, 1997.

[30] Marshall E.J.P., Weed distributions associated with cereal field edges: some preliminary observations, Aspects Appl. Biol. 9 (1985) 49-58.

[31] Marshall E.J.P., Distribution patterns of plant associated with arable field edges, J. Appl. Ecol. 26 (1989) 247-257.

[32] Marshall E.J.P., Smith B.D., Field margin flora and fauna: interaction with agriculture, in: Way J.M., Greig-Smith P.W. (Eds.), Field Margins, British Crop Protection Council, Croydon, 1987, pp. 23-33.

[33] McCloskey M., Firbank L.G., Watkinson A.R., Webb D.J., The dynamics of experimental arable weed communities under different management practices, J. Veg. Sci. 7 (1996) 799-808.

[34] Muller E.M., Seedlings of North-western European Lowland, Junk, The Hague, 1978.

[35] Olivereau F., Les plantes messicoles des plaines françaises, Courr. Environ. Inra 28 (1996) 5-18.

[36] Palmer M.W., Maurer T.A., Does diversity beget diversity? A case study of crops and weeds, J. Veg, Sci. 8 (1997) 235-240.

[37] Pysek P., Leps J., Response of a weed community to nitrogen fertilization: a multivariate analysis, $\mathrm{J}$. Veg. Sci. 2 (1991) 237-244.

[38] Roberts H.A., Seed bank in soils, Adv. Appl. Biol. 6 (1981) 1-55. 
[39] Svensson R., Wigren M., A survey of the history, biology and preservation of some retreating synanthropic plants, Symbolae Botanicae Upsaliensis 25 (1986) 4-5.

[40] Torre F., Chessel D., Co-structure de deux tableaux totalement appariés, Rev. Stat. Appl. 23 (1995) 109-21.

[41] Tutin T.G. et al., Flora Europaea, Cambridge University Press, Cambridge, 1964-1980.

[42] van Elsen T., Scheller U., Zur Bedeutung einer stark gegliederten Feldflur für die Entwicklung von Ackerwildkraut-gesellschaften. Naturschutz und
Landschaftespflege in Brandenburg Sonderheft, Naturschutz in der Agrarlandschaft 1 (1994) 17-31

[43] Wilson P.J., Botanical diversity in arable field margins, in: Boatman N. (Eds.), Field Margins: Integrating Agriculture and Conservation, British Crop Protection Council, Croydon, 1994, pp. 53-58.

[44] Wilson P.J., Conserving the flora of arable field margins - how much does it cost?, The 1997 Brighton Crop Protection Conference - Weeds, 1997, 991-996.

[45] Wilson P.J., Aebischer N.J., The distribution of dicotylenous arable weeds in relation to distance from the field edge, J. Appl. Ecol. 32 (1995) 295-310. 